can be paid for out of future earnings, but the economists who addressed the Royal Economics Society were convinced that their evidence pointed to increased fees being a considerable disincentive to less-advantaged students even with a more favorable loan scheme. Moreover, while the report is notably balanced in the way it presents its arguments and in particular in the way it advocates the redirection of fee income into bursaries for the disadvantaged, it does not address the probable plight of those universities that are at the bottom of the league tables but that are addressing the government's access agenda as vigorously as those at the top are addressing its research agenda. Their position offers the sharpest conflict between the government's twin policies of market orientation and social inclusion. The introduction of higher fees would certainly favor the top universities but at the expense of the bottom; the bottom are delivering social inclusivity, but the top are not for the reasons described above and, once freed from government constraints, might be even less likely to do so.

The debate will no doubt continue until after the next general election, but the fear must be that attitudes will polarize either because one or the other of the main political parties endorses some elements of the debate or because the argument becomes increasingly institutionally self-interested. The dilemmas it exposes are not, of course, limited to the United Kingdom.

\title{
The Foreign Invasion of Israeli Higher Education
}

\section{Roxana G. Reichman}

Roxana G. Reichman is assistant professor at Gordon Teachers College, Haifa, Israel. E-mail: <reichmanr@hotmail.com>.

$\mathrm{T}$ here is an entirely new trend in Israeli higher education-a new diversification in the nation's system of postsecondary education. Currently, only 56 percent of the 199,000 Israeli students study at one of the country's seven main universities-20 percent at one of the colleges (including teachers education colleges), 16 percent at the Open University, and 8 percent at one of the branches of foreign universities that have opened during the last decade (most of which are British or American). There are various ways of looking at this new dynamism in Israeli higher education. It is, of course, encouraging to see that the system has almost doubled in size within 15 years. That means greater access to postsecondary education, especially for those students who have historically been underprivileged. The bad news is that some of the branch campuses of foreign academic institutions offer quick degrees, with no attention whatsoever to academic standards, no basic facilities such as libraries, computers, etc., and a teaching staff whose qualifications are sometimes questionable. Other branches make a significant effort to meet standards while at the same time answering the needs of the population they serve. The 15,000 students who could not gain access to any of the "traditional" institutions of higher education are willing to pay a tuition almost twice as high as that charged by public higher education institutions because they want to get a degree without having to give up their full-time jobs or, in some cases, without having to devote themselves to hard intellectual work. They see the degree as a means for social mobility or simply as a way to further their careers, and

they don't mind the lack of intellectual dialogue that is supposed to characterize any meaningful education at this level. It is important to stress that more than responding to an existing demand, these institutions have themselves created a new demand. The issue of accountability has not received the attention it deserves.

The Council of Higher Education (CHE) decided to open the gates of higher education to foreign institutions because of public pressure at the beginning of the 1990s. Since these institutions belong to the private sector, for which the financial bottom line is the most important criteria and where self-regulation can sometimes be almost nonexistent, the CHE realizes that developments in this arena might threaten the reputation of any degree and of any university. Five main guidelines have to be met by any foreign university in order to be recognized in Israel. These guidelines need to be analyzed in the light of the main goal, which is quality control and accountability.

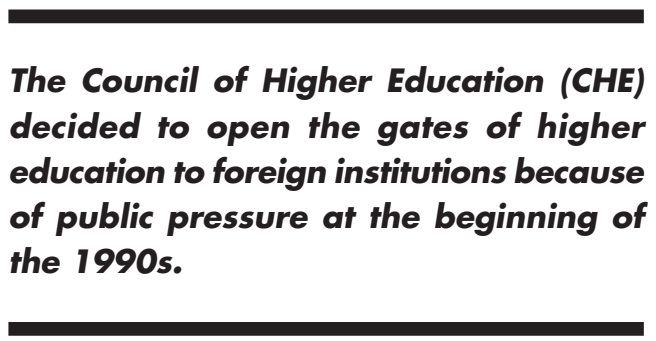

First, any branch of a foreign university will have to prove that the time needed to complete the degree is similar to that required by Israeli universities. The CHE does not oppose creative measures-such as, three semesters a year instead of two semesters at the traditional universities-but it wants to prevent a situation in which a degree is awarded to persons who do not have the necessary knowledge in their respective fields.

Second, all students who are accepted will either have passed the matriculation exams that are prerequisites for 
admission to any Israeli university or will be 30 years of age or older. This requirement is crucial since some of the branches of foreign universities have been willing to accept all high school graduates, regardless of their credentials. Starting last year, this is no longer possible.

Third, all the institutions will offer programs that are similar to the ones the mother institution offers in their home country. This requirement presents some important advantages as well as some serious challenges regarding issues that are sometimes difficult to address. The CHE makes a serious attempt to preserve the academic level, but this colonization creates a real dilemma for the coordinators, who would like to adapt the curriculum to the needs of the local student. It makes sense for a master's student in education who wants to specialize in curriculum to analyze the existing curriculum in Israel rather than the one in Britain or in the United States-just as it makes sense for a master's student in business to analyze a local institution rather than a foreign one. In addition, the issue of academic freedom has to be addressed when faculty members are not allowed to make any changes in the existing curriculum in order to ensure that the syllabus remains similar to the one in the foreign institution. The CHE seems to have concluded that the public interest in Israel today requires stressing social mobility at the expense of academic freedom.

Fourth, the teaching staff at these institutions will be required to have qualifications that will be similar to those of the teaching staff in their country of origin. This is very important because in Israeli universities only people having a terminal degree can teach graduate students, while at the different branches of foreign universities, people with a master's degree or even people working toward one have been found teaching graduate students studying for the master's degree. It should be noted that some of the staff from the original institutions use distance learning, and some university professors from the seven traditional Israeli universities who are looking for an extra job have joined the staff. The ethical considerations involved have not yet even been raised.

Fifth, the institutions will have to prove that they have the necessary facilities for adequate intellectual work-such as, libraries, computers, etc. This requirement will prevent foreign universities from opening small branches that consist of only a few classes, without any facilities whatsoever. As a result of this move on the part of the CHE, there was a significant change, and the picture has become quite diverse. At an October 1999 meeting of the Education Committee of the Israeli Parliament, the minister of education stated that the ministry would make certain that all foreign universities would become accountable and would be judged on their quality and relevance and that he would make decisions on this issue on an individual basis. Seven institutions had to close down during the first six months of 2000 since they were not able to meet these demands; others are in the process of closing down (the students who have started the programs will be allowed to graduate but no new students are being accepted); and still others have changed their curriculum, closed some local branches that lacked the necessary facilities, and made significant changes in their teaching staff.

One can only hope that all higher education institutions will be accountable for their quality, respond to the needs of local students, and pay more attention to the issue of academic freedom.

\section{East German Universities Ten Years After}

\section{Peer Pasternack}

Peer Pasternack is a researcher at the Institute for Higher Education Research, Universität Halle-Wittenberg. He is editor of Hochschule-Ost and lecturer at the Institute of Political Science, University of Leipzig. Address: Collegienstr 62B, D 06886 Lutherstadt-Wittenberg, Germany. E-mail: <pasternack@hof.uni-halle.de>.

$\mathrm{G}$ ermany today is a country with two societies-West I and East - divided by a virtual wall. Though a higher education system and society are never completely congruent, the distribution of staff and students reveals significant patterns. Only one-third of the highest-ranking professorships (C4) in East Germany are now held by East Germans, and an East German professor in a West German university is an uncommon occurance. The propor- tion of West German students in East Germany and the proportion of East German students in West Germany are mirror images of each other. Only 2 percent of students who were born in West Germany study at East German universities, but 14 percent of students who grew up in East Germany study in West Germany.

Apart from these factors, East German higher education institutions are characterized by both advantages and problems. First of all, the equipment at East German universities is more modern than that in many West German universities, having been almost completely updated in the last few years. The staff-to-student ratio is very favorable in many disciplines. East German academic staff are more highly motivated to teach and advise students than are their West German colleagues. These are the main advantages.

First among the important problems is the aftereffect of the changes in the university system over the last ten years. Exhaustion can be noted due to the turmoil of institutional transformation. For this reason, East German uni- 